\title{
Patient's Perspectives on Team-Based Care by a Clinical Pharmacist: Case Report
}

\author{
Meagen Rosenthal, Mark J Makowsky, Ross T Tsuyuki and Helen M Madill
}

\section{INTRODUCTION}

$\mathrm{T}$ he Capturing Outcomes of Clinical Activities Performed by a Rounding Pharmacist Practicing in a Team Environment (COLLABORATE) study was a controlled clinical trial that demonstrated the beneficial effect of team-based care by a clinical pharmacist on process-of-care and patient outcomes in hospital patients cared for by internal and family medicine teams. ${ }^{1}$ During the course of the study, several patients or their family members offered positive comments about the teambased clinical pharmacist services. These cases came to the authors' attention during weekly investigator meetings and via pharmacists' reflective journals, which were kept as a mechanism to capture pharmacists' experiences in working with the rounding medical team. ${ }^{2}$ Since the overall research plan did not allow for a systematic evaluation of patient satisfaction with the service provided by pharmacists, it was decided to attempt to systematically capture comments from patients in another way, with a view to better understanding and demonstrating the impact of team-based delivery of clinical pharmacist services from the patient's perspective.

\section{METHODS}

Information provided by the 2 team-based pharmacists involved in the COLLABORATE study was used to retrospectively (i.e., near the end of the 1-year study period) identify patients who had demonstrated willingness to "act as a reference" for the study pharmacists as a result of the care provided during the study. This patient identification scheme was chosen because it was impossible to contact the entire population of patients who had interacted with the team-based pharmacist, since the requirement for patient consent had been waived in the original COLLABORATE study.

Three potential patients were identified and were approached by telephone to participate in a face-to-face semistructured interview. One patient and her husband/ caregiver agreed to participate in the interview, and the pharmacist's reflective journal was screened for any comments pertaining to this case. The interview was designed to let the patient and caregiver tell their versions of the events that occurred during the hospital stay, particularly their experience working with the pharmacist and the impact of the pharmacist's care on the patient's recovery and future ability to manage her medications.

The study protocol was approved by the Ethics Review Board of the University of Alberta, and informed consent was obtained from the participants.

\section{RESULTS}

The following passage from the pharmacist's reflective journal provided some background to the case:

A 66 year old patient was admitted with pneumonia. She also had a history of very severe GERD [gastroesophageal reflux disease], including esophagitis and asthma related to GERD. The GERD was actually her biggest ongoing concern, not the pneumonia she was admitted with. I had a few ideas of drug-related strategies to possibly minimize the GERD. For example, patient stated she was taking amitriptyline $150 \mathrm{mg}$ daily, yet refill records showed doses in excess of $200 \mathrm{mg}$ daily. Since tricyclic antidepressants can decrease lower esophageal sphincter tone and exacerbate GERD, we significantly reduced the dose. However, I don't think my biggest impact was a clinical one with this patient. I ended up spending a significant amount of time with the patient and her husband, answering questions, discussing her medical issues etc. and I made them a medication list for discharge, which the husband requested I e-mail to him so he could modify it over time as her meds changed.

During the interview, the couple was particularly interested in discussing the discharge medication summary that had been sent to them by e-mail (Figure 1). The patient's husband had put the data into an Excel file that could be continually updated and printed. He reported that "The [community] pharmacist has this copy [and] the doctor has this copy; so they are all on the same wavelength."

In particular, when the patient and her husband took the document to the community pharmacist, it proved invaluable during discussions about the patient's medications: "Because 


\begin{tabular}{|c|c|c|c|c|c|c|}
\hline \multicolumn{3}{|c|}{$\begin{array}{l}\text { MEDICATION SCHEDULE } \\
\text { DISCHARGE DATE: }\end{array}$} & \multicolumn{4}{|c|}{ Allergies/Intolerance: Salbutamol (rash) } \\
\hline Medication & Directions & Reason & Breakfast & Lunch & Dinner & Bedtime \\
\hline $\begin{array}{l}\text { Didrocal Kit } \\
\text { (Etidronate } 400 \mathrm{mg} / \text { Calcium 500mg) }\end{array}$ & Take 1 tablet daily & Osteoporosis & & & & 1 \\
\hline Calcium Carbonate $500 \mathrm{mg}$ tablet & Take 1 tablet twice daily & Osteoporosis & & 1 & 1 & \\
\hline Vitamin D 400 IU capsule & Take 2 capsules daily & Osteoporosis & 2 & & & \\
\hline $\begin{array}{l}\text { Estradiol 1mg tablet } \\
\text { (Estrace) }\end{array}$ & $\begin{array}{c}\text { Take } 1 \text { tablet daily for } 3 \text { weeks, then } \\
\text { off for } 1 \text { week }\end{array}$ & Estrogen replacement & $\begin{array}{c}1 \\
\text { (cycled) }\end{array}$ & & & \\
\hline $\begin{array}{l}\text { Levothyroxine } 150 \mathrm{mcg} \text { tablet } \\
\text { (Synthroid) }\end{array}$ & Take 1 tablet once daily & Thyroid & 1 & & & \\
\hline $\begin{array}{l}\text { Atenolol } 50 \mathrm{mg} \text { tablet } \\
\text { (Tenormin) }\end{array}$ & Take $1 / 2$ tablet (25mg) twice a day & $\begin{array}{c}\text { Blood pressure } \\
\text { Migraine Prevention }\end{array}$ & $1 / 2$ & & & $1 / 2$ \\
\hline $\begin{array}{l}\text { Lansoprazole } 30 \mathrm{mg} \text { capsule } \\
\text { (Prevacid) }\end{array}$ & $\begin{array}{c}\text { Take } 1 \text { capsule three times daily, } 15- \\
30 \text { min before meals }\end{array}$ & Reflux & 1 & 1 & 1 & \\
\hline $\begin{array}{l}\text { Domperidone } 10 \mathrm{mg} \text { tablet } \\
\text { (Motilium) }\end{array}$ & $\begin{array}{l}\text { Take } 2 \text { tablets four times a day, } 30 \\
\text { minutes before meals }\end{array}$ & Reflux & 2 & 2 & 2 & 2 \\
\hline $\begin{array}{l}\text { Ranitidine } 300 \mathrm{mg} \text { tablet } \\
\text { (Zantac) }\end{array}$ & Take 1 tablet every bedtime & Reflux & & & & 1 \\
\hline $\begin{array}{l}\text { Gabapentin } 100 \text { mg capsule } \\
\text { (Neurontin) }\end{array}$ & Take 1 capsule four times a day & Neuropathic pain & 1 & 1 & 1 & 1 \\
\hline $\begin{array}{l}\text { Amitriptyline } 50 \mathrm{mg} \text { tablet } \\
\text { (Elavil) }\end{array}$ & Take 2 tablets at bedtime & Neuropathic pain & & & & 2 \\
\hline $\begin{array}{l}\text { Montelukast } 10 \mathrm{mg} \text { tablet } \\
\text { (Singulair) }\end{array}$ & Take 1 tablet every bedtime & Asthma & & & & 1 \\
\hline $\begin{array}{l}\text { Budesonide/Formoterol inhaler } \\
\text { (Symbicort 200) }\end{array}$ & $\begin{array}{c}\text { Inhale } 2 \text { puffs twice daily (Rinse } \\
\text { mouth after use) }\end{array}$ & Asthma/Breathing & 2 & & & 2 \\
\hline $\begin{array}{l}\text { Tiotropium } 18 \mathrm{mcg} \text { capsule } \\
\text { (Spiriva) }\end{array}$ & Inhale the contents of 1 capsule daily & Asthma/Breathing & 1 & & & \\
\hline \multicolumn{7}{|c|}{ Following medications to be taken as needed: } \\
\hline \multicolumn{7}{|c|}{$\begin{array}{l}\text { Tylenol Regular or Tylenol \#4 - Take } 1-2 \text { tablets four times daily as needed for pain. } \\
\text { Zolmitriptan } 2.5 \mathrm{mg} \text { Rapimelt tablets (Zomig) Take } 1 \text { tablet as needed for migraine. May repeat after } 2 \text { hours, if migraine returns. } \\
\text { Fenoterol } 0.1 \mathrm{mg} / \text { puff (Berotec) inhaler - Inhale } 1-2 \text { puffs every } 4 \text { hours as needed. } \\
\text { Ipratopium } 20 \mathrm{mcg} / \text { puff inhaler (Atrovent) - Inhale } 2 \text { puffs every } 4 \text { hours as needed. }\end{array}$} \\
\hline \multicolumn{7}{|c|}{$\begin{array}{l}\text { - Decreased amitriptyline dose (can potentially exacerbate reflux) } \\
\text { - Added ranitidine at bedtime for reflux } \\
\text { - Increased lansoprazole dose for reflux }\end{array}$} \\
\hline
\end{tabular}

Figure 1. Discharge medication summary for a 66-year-old patient admitted with pneumonia. (c) 2006 Grey Nuns Community Hospital (now part of Alberta Health Services). Reproduced by permission of the institution and the patient involved.

there's so many doctors that give prescriptions . . . they don't know what the other doctor's doing. After a couple of years, these medications build up to such an inventory. So [with the community pharmacist] at [the local pharmacy], we took the sheet and went through it one-by-one, and cut back and cut back, and that's the pharmacy, the pharmacist really helped. And she's [the patient] been a lot better since."

\section{DISCUSSION}

Although the discharge care provided in this case did not meet the definition of a core clinical pharmacy service as set out by Bond and others, ${ }^{3}$ this case highlights the value that one patient and her caregiver placed on medication education and discharge counselling provided by a hospital pharmacist at the time of discharge. In addition, it illustrates that provision of an up-to-date medication summary to the patient at the time of discharge can improve coordination of care between hospital and community pharmacists during transitions and can facilitate the provision of safe and effective medication therapy by community care providers.

Although a prospective patient satisfaction survey or a series of cases would have been better for capturing a broad range of opinions about clinical pharmacist services, neither methodology was deemed feasible for the COLLABORATE study. We therefore chose to highlight this case as an example of a positive interaction between a pharmacist and a patient. Although pharmacists are typically nameless and faceless within inpatient care, integration of the hospital pharmacist into the medical team during the COLLABORATE study allowed for more face-to-face interaction with patients than is typical. As a result, one more family knows the role that pharmacists play in patient care.

\section{References}

1. Makowsky MJ, Koshman SL, Midodzi WK, Tsuyuki RT. Capturing outcomes of clinical activities performed by a rounding pharmacist practicing in a team environment: the COLLABORATE trial. Med Care 2009; $47(6): 642-650$. 
2. Makowsky MJ, Schindel TJ, Rosenthal M, Campbell K, Tsuyuki RT, Madill HM. Collaboration between pharmacists, physicians and nurse practitioners: a qualitative investigation of working relationships in the inpatient medical setting. J Interprof Care 2009;23(2):169-184.

3. Bond CA, Raehl CL, Patry R. Evidence-based core clinical pharmacy services in United States hospitals in 2020: services and staffing. Pharmacotherapy 2004;24(4):427-40.

Meagen Rosenthal, BA, MA, is with Epidemiology Coordinating and Research (EPICORE) Centre/Centre for Community Pharmacy Research and Interdisciplinary Strategies (COMPRIS), Edmonton, Alberta.

Mark J Makowsky, BSP, PharmD, ACPR, is with the Faculty of Pharmacy and Pharmaceutical Sciences, University of Alberta, Edmonton, Alberta.

Ross T Tsuyuki, PharmD, MSc, is with Epidemiology Coordinating and Research (EPICORE) Centre/Centre for Community Pharmacy Research and Interdisciplinary Strategies (COMPRIS), and the Faculty of Pharmacy and Pharmaceutical Sciences, University of Alberta, Edmonton, Alberta.
Helen M Madill, PhD, RPsych, is with the Centre for Health Promotion Studies, School of Public Health, University of Alberta, Edmonton, Alberta.

\section{Address correspondence to:}

Dr Ross T Tsuyuki

Epidemiology Coordinating and Research (EPICORE) Centre

University of Alberta

220 College Plaza

Edmonton AB T6G 2C8

e-mail: ross.tsuyuki@ualberta.ca

\section{Acknowledgements}

We acknowledge Rita Murray for her transcription services and Lisa Tate and Dayle Struhan, the study pharmacists. Dr Tsuyuki is supported by the University of Alberta/Merck Frosst/ Aventis Chair in Patient Health Management. 